\title{
Hubungan Kemungkinan Depresi dengan Kualitas Hidup pada Lanjut Usia di Kelurahan Surau Gadang Wilayah Kerja Puskesmas Nanggalo Padang
}

\author{
Ayu Wulandari Utami ${ }^{1}$, Rini Gusya Liza $^{2}$, Taufik Ashal $^{3}$
}

\begin{abstract}
Abstrak
Lanjut usia adalah individu yang telah berusia lebih dari 60 tahun. Depresi merupakan masalah psikologis yang sering terjadi pada lanjut usia yang ditandai dengan perasaan sedih, sehingga dapat mempengaruhi aktivitas fisik seseorang. Kualitas hidup adalah penilaian individu terhadap posisinya di dalam kehidupan dalam konteks untuk melaksanakan fungsinya pada kehidupan sehari-hari. Tujuan penelitian ini adalah menentukan hubungan kemungkinan depresi dengan kualitas hidup pada lanjut usia di Kelurahan Surau Gadang wilayah kerja Puskesmas Nanggalo Padang. Penelitian ini merupakan studi analitik dengan desain cross sectional yang dilaksanakan dari Desember 2017 sampai Mei 2018 di Kelurahan Surau Gadang wilayah kerja Puskesmas Nanggalo Padang. Sampel berjumlah 100 orang yang terdiri dari 50 orang lansia berkemungkinan depresi dan 50 orang lansia berkemungkinan tidak depresi. Pengumpulan data dilakukan dengan mewawancarai subjek menggunakan instrumen Geriatric Depression Scale dan WHOQOLBREF. Penentuan sampel menggunakan teknik stratified proportionate random sampling dan pengambilan sampel menggunakan consecutive sampling. Analisis data menggunakan analisis univariat dan analisis bivariat dengan uji Chi-Square. Hasil analisis univariat didapatkan distribusi frekuensi kualitas hidup lanjut usia yaitu $86 \%$ memiliki kualitas hidup baik dan $14 \%$ memiliki kualitas hidup buruk. Hasil analisis bivariat menunjukkan terdapat hubungan bermakna antara kemungkinan depresi dengan kualitas hidup $(p=0,004)$. Simpulan penelitian ini adalah terdapat hubungan bermakna antara kemungkinan depresi dengan kualitas hidup pada lanjut usia di Kelurahan Surau Gadang.
\end{abstract}

Kata kunci: lanjut usia, depresi, kualitas hidup

\begin{abstract}
Elderly are persons who are over 60 years old. Depression is one of psychological problem that often occur in elderly people indicated by a sadness and it would influence someone's physical activity. Quality of life is individual's perception of their position in daily life. The objective of this study was to determine the relation between probability depression and quality of life in elderly people in Surau Gadang Region in work field of primary healthcare Nanggalo Padang. This was an analytical experiment with cross sectional design that had been conducted in December 2017 till May 2018 in Surau Gadang Region in workfield of primary healthcare Nanggalo Padang. A total of one hundred samplings consist of fifty probability depressed elderly and fifty probability non-depressed elderly. The data were collected by interviewing the subject using Geriatric Depression Scale and WHOQOL-BREF instrument. The sample was decided using stratified proportionate random sampling technique and sampling using consecutive sampling technique. The data were analyzed by univariate analysis and bivariate analysis with Chi-square test. Result of univariate analysis was distribution of quality of life in elderly, in which $86 \%$ having good quality of life and $14 \%$ having bad quality of life. The bivariate analysis showed that there were significant relationship between depression and quality of life in elderly ( $p=$ 0.004). The conclusion is a significant relationship between depression and quality of life in elderly in Surau Gadang.
\end{abstract}

Keywords: Elderly, depression, quality of life 
Affiliasi penulis: 1. Prodi Kedokteran Fakultas Kedokteran Universitas Andalas Padang (FK Unand), 2. Bagian IImu Psikiatri FK UNAND/RSUP M.Djamil Padang, 3. Bagian IImu Psikiatri FK UNAND/RSUP M.Djamil Padang

Korespondensi: Ayu Wulandari Utami, Email:

ayuwulandariutami@yahoo.co.id Telp: 085766475671

\section{PENDAHULUAN}

Lanjut usia adalah seseorang yang telah mencapai usia 60 (enam puluh) tahun ke atas. ${ }^{1}$ Secara global pada tahun 2013, proporsi penduduk berusia lebih dari 60 tahun adalah $13,4 \%$ dari total populasi penduduk dunia. $^{2}$ Jumlah lansia diperkirakan akan terus meningkat baik di negara maju maupun negara berkembang, termasuk Indonesia. ${ }^{2,3,4}$ Pada tahun 2016, di Indonesia diperkirakan memiliki jumlah penduduk lansia sekitar 258,70 juta jiwa atau 8,69 persen dari jumlah keseluruhan penduduk Indonesia. ${ }^{5}$ Pada tahun 2017, persentase lansia di Indonesia mencapai 9,03\% dari keseluruhan penduduk. Sumatera Barat berada pada peringkat ke-6 dari keseluruhan provinsi di Indonesia dengan persentase penduduk lansia 9,25 \% dari keseluruhan penduduk Sumatera Barat pada tahun $2017 .^{3}$

Peningkatan jumlah lansia dapat membawa dampak positif apabila penduduk lansia berada dalam keadaan sehat, aktif dan produktif. ${ }^{3} \mathrm{Di}$ sisi lain, peningkatan jumlah lansia juga dapat menimbulkan berbagai masalah yang jika tidak di tangani dengan baik akan menjadi masalah yang kompleks. ${ }^{3,6}$ Secara biologis, lansia akan mengalami perubahan yang mengarah pada kemunduran kesehatan secara fisik dan psikis. ${ }^{7}$ Seiring bertambahnya usia para lansia juga mengalami berbagai permasalahan mulai dari kehilangan pekerjaan, kehilangan tujuan hidup, kehilangan teman, risiko terkena penyakit, terisolasi dari lingkungan, dan kesepian. Hal tersebut dapat memicu terjadinya gangguan mental, salah satu yang paling banyak di jumpai pada lansia adalah depresi. ${ }^{4}$

Depresi merupakan salah satu masalah kesehatan yang serius di masyarakat. ${ }^{8}$ Menurut World Health Organization (WHO), depresi merupakan suatu gangguan mental umum yang ditandai dengan suasana hati yang tertekan, kehilangan kesenangan atau minat,merasa kurang energi, perasaan bersalah atau rendah diri, gangguan makan atau tidur, dan konsentrasi yang rendah. Pada tahun 2015, lebih dari
300 juta orang diperkirakan menderita depresi atau setara dengan $4,4 \%$ populasi dunia. Depresi dapat terjadi pada siapa saja. ${ }^{9}$ Gejala depresi hampir muncul pada $20 \%$ lansia yang tinggal di masyarakat. ${ }^{10}$ Kualitas hidup atau Quality of life merupakan penilaian individu terhadap aspek positif dan negatif dalam kehidupannya. ${ }^{11}$ Kualitas hidup yang baik adalah sesuatu yang harus di jaga pada lansia, karena hidup yang berkualitas merupakan kondisi yang optimal bagi lansia untuk kehidupannya sehari-hari sehingga mereka bisa menikmati masa tuanya dengan bahagia, bermakna dan dapat berguna bagi orang-orang disekitarnya. ${ }^{6}$

Berdasarkan penelitian yang pernah dilakukan oleh Rasquinha dan Acharya di Ujire India terdapat hubungan yang signifikan antara depresi dengan kualitas hidup pada lansia yang berada di panti jompo. $^{12}$ Penelitian Haris di Kelurahan Kali Anyar Jakarta Barat pada tahun 2014 dan didapatkan 19,6\% lansia mengalami depresi dan $38 \%$ mengalami depresi disertai kualitas hidup rendah. $^{13}$ Penelitian yang dilakukan oleh Miftahul Hayati tahun 2015 di salah satu wilayah di Kelurahan Surau Gadang didapatkan angka kejadian depresi pada lansia yang cukup tinggi yaitu $84 \%$ lansia yang mengalami depresi. ${ }^{14}$

Berdasarkan uraian di atas peneliti tertarik melakukan penelitian untuk mengetahui hubungan kemungkinan depresi dengan kualitas hidup pada lanjut usia di Kelurahan Surau Gadang wilayah kerja Puskesmas Nanggalo Padang.

\section{METODE}

Jenis penelitian ini adalah analitik dengan rancangan cross sectional. Variabel independen adalah kemungkinan depresi dan variabel dependen adalah kualitas hidup. Penelitian dilakukan dari Desember 2017 sampai Mei 2018 di Kelurahan Surau Gadang wilayah kerja Puskesmas Nanggalo Padang Sumatera Barat.

Populasi penelitian ini adalah seluruh lansia yang berdomisili di Kelurahan Surau Gadang wilayah kerja Puskesmas Nanggalo Padang. Sampel penelitian yang dipilih adalah lansia yang berdomisili di Kelurahan Surau Gadang wilayah kerja Puskesmas Nanggalo Padang yang memenuhi kriteria inklusi dan 
kriteria eksklusi. Kriteria inklusi subjek: Individu yang berusia 60 tahun keatas, bertempat tinggal di kelurahan Surau Gadang wilayah kerja Puskesmas Nanggalo Padang, bersedia menjadi responden penelitian dan tidak memiliki gangguan kognitif. Kriteria eksklusi subjek: Tidak bersedia mengikuti penelitian dan subjek tidak sanggup mengikuti penelitian (hambatan komunikasi, mengalami gangguan jiwa, sakit berat dan keadaan lainnya yang mengakibatkan kesulitan dalam memperoleh data).

Data diperoleh dari wawancara menggunakan kuesioner Geriatric Depression Scale-15 yang dikutip dari Das et al (2014) untuk menentukan kemungkinan depresi. ${ }^{8}$ Kuesioner World Health Organization Quality of Life (WHOQOL)-BREFyang dikutip dari Sutikni (2011) untuk menentukan kualitas hidup. ${ }^{6}$ Data dianalisis secara statistik berdasarkan variabel yang dinilai menggunakan sistem komputerisasi yaitu analisis univariat dan bivariat. Analisis univariat dilakukan untuk melihat distribusi frekuensi dari masing-masing variabel independen dan variabel dependen. Analisis bivariat dilakukan untuk menganalisis hubungan antara variabel independen dan variabel dependen. Hubungan dua variabel tersebut dianalisis dengan menggunakan uji Chi-Square dan dikatakan bermakna bila $\mathrm{p}<0.05$.

\section{HASIL}

Penelitian ini dilakukan terhadap 100 orang responden yang terdiri dari 50 orang lansia yang berkemungkinan mengalami depresi dan 50 orang lansia tidak berkemungkinan mengalami depresi di Kelurahan Surau Gadang wilayah kerja Puskesmas Nanggalo Padang. Pengumpulan data dilakukan di Posyandu lansia dan kunjungan ke rumah lansia sejak 3 April 2018 sampai 18 April 2018.

Berdasarkan Tabel 1 didapatkan bahwa sebagian besar responden berada pada rentang usia 60-74 tahun yaitu sebanyak $82 \%$, dengan rerata usia 68,64 tahun. Sebagian besar responden berjenis kelamin perempuan yaitu sebanyak $73 \%$. Dilihat dari pendidikan terakhir yang dimiliki oleh responden yang terbanyak adalah pada tingkat SMA/Sederajat yaitu sebanyak $34 \%$.
Tabel 1. Karakteristik responden

\begin{tabular}{|c|c|c|c|}
\hline \multirow{3}{*}{ Karakteristik } & \multicolumn{2}{|c|}{ Kejadian Depresi } & \multirow{3}{*}{$\begin{array}{c}\text { Rerata } \\
\text { (SD) }\end{array}$} \\
\hline & $\begin{array}{c}\text { Mungkin } \\
\text { Tidak } \\
\text { Depresi }\end{array}$ & $\begin{array}{l}\text { Mungkin } \\
\text { Depresi }\end{array}$ & \\
\hline & $\mathbf{f ( \% )}$ & $\mathbf{f ( \% )}$ & \\
\hline \multicolumn{3}{|l|}{ Usia } & \multirow{3}{*}{$\begin{array}{c}68,64 \\
(6,089)\end{array}$} \\
\hline $60-74$ & $42(51,2)$ & $40(48,8)$ & \\
\hline $75-90$ & $8(44,4)$ & $10(55,6)$ & \\
\hline \multicolumn{4}{|l|}{ Jenis Kelamin } \\
\hline Laki-laki & $14(51,9)$ & $13(48,1)$ & \\
\hline Perempuan & $36(49,3)$ & $37(50,7)$ & \\
\hline \multicolumn{4}{|l|}{$\begin{array}{l}\text { Pendidikan } \\
\text { terakhir }\end{array}$} \\
\hline Tidak Sekolah & $3(75)$ & $1(25)$ & \\
\hline SD/Sederajat & $7(46,7)$ & $8(53,3)$ & \\
\hline SMP/Sederajat & $7(31,8)$ & $15(68,2)$ & \\
\hline SMA/Sederajat & $18(52,9)$ & $16(47,1)$ & \\
\hline \multicolumn{4}{|l|}{ Akademi/ } \\
\hline Perguruan & $15(60)$ & $10(40)$ & \\
\hline \multicolumn{4}{|l|}{ Tinggi } \\
\hline \multicolumn{4}{|l|}{ Status } \\
\hline \multicolumn{4}{|l|}{ Perkawinan } \\
\hline Menikah & $34(57,6)$ & $25(42,4)$ & \\
\hline Janda & $16(42,1)$ & $22(57,9)$ & \\
\hline Duda & $0(0)$ & $3(100)$ & \\
\hline \multicolumn{4}{|l|}{ Pekerjaan } \\
\hline Bekerja & $16(59,3)$ & $11(40,7)$ & \\
\hline Tidak Bekerja & $34(46,6)$ & $39(53,4)$ & \\
\hline
\end{tabular}

Status perkawinan, pada responden terbanyak berstatus menikah yaitu sebanyak 59\%. Kemudian, dilihat dari pekerjaan pada responden mayoritas berstatus tidak bekerja yaitu sebanyak $73 \%$.

Berdasarkan tabel diatas, 55,6 \% responden berkemungkinan depresi berada pada rentang usia 75-90 tahun. Sedangkan, pada responden yang berkemungkinan tidak depresi 51,2 \% berada pada rentang 60-74 tahun. Pada kelompok kemungkinan depresi $50,7 \%$ berjenis kelamin perempuan, tetapi pada kelompok kemungkinan tidak depresi 51,9\% berjenis kelamin laki-laki. Pendidikan terakhir yang dimiliki oleh responden kemungkinan depresi adalah SMP/Sederajat (68,2\%). sedangkan pada kelompok kemungkinan tidak depresi adalah tingkat SMA/Sederajat (52,9\%). Dilihat dari segi status perkawinan pada kelompok kemungkinan depresi yang 
terbanyak adalah yang berstatus duda (100\%), di sisi lain pada kelompok yang kemungkinan tidak depresi sebanyak $57,6 \%$ berstatus menikah. Dilihat dari pekerjaan, sebesar 53,4\% lanjut usia pada kelompok berkemungkinan depresi adalah tidak bekerja. Sedangkan, pada kelompok berkemungkinan depresi $59,3 \%$ nya adalah bekerja.

Tabel 2. Distribusi frekuensi kualitas hidup pada lansia

\begin{tabular}{rcc}
\hline Kualitas Hidup & $\mathbf{f}$ & $\%$ \\
\hline Baik & 86 & 86 \\
Buruk & 14 & 14 \\
\hline Total & 100 & 100 \\
\hline
\end{tabular}

Berdasarkan tabel di atas didapatkan bahwa sebanyak $86 \%$ lansia memiliki kualitas hidup baik dan sebanyak 14\% lansia memiliki kualitas hidup buruk.

Tabel 3. Distribusi frekuensi kualitas hidup pada masing-masing domain pada lansia

\begin{tabular}{lccccccccc}
\hline \multirow{2}{*}{$\begin{array}{c}\text { Kualitas } \\
\text { Hidup }\end{array}$} & $\begin{array}{c}\text { Domain } \\
\text { Fisik }\end{array}$ & \multicolumn{2}{c}{$\begin{array}{c}\text { Domain } \\
\text { Psikologis }\end{array}$} & $\begin{array}{c}\text { Domain } \\
\text { Hubungan } \\
\text { Sosial }\end{array}$ & \multicolumn{2}{c}{$\begin{array}{c}\text { Domain } \\
\text { Lingkungan }\end{array}$} \\
\cline { 2 - 9 } & $\mathbf{f}$ & $\%$ & $\mathbf{f}$ & $\%$ & $\mathbf{f}$ & $\%$ & $\mathbf{f}$ & $\%$ \\
\hline Baik & 64 & 64 & 54 & 54 & 54 & 54 & 95 & 95 \\
Buruk & 36 & 36 & 46 & 46 & 46 & 46 & 5 & 5 \\
\hline Jumlah & 100 & 100 & 100 & 100 & 100 & 100 & 100 & 100 \\
\hline
\end{tabular}

Berdasarkan Tabel 3 didapatkan 64\% lansia memilki kualitas hidup domain fisik yang baik, 54\% dengan kualitas hidup domain psikologis dan domain hubungan sosial yang baik, dan 95\% dengan kualitas hidup domain lingkungan yang baik.

Tabel 4. Hubungan depresi dengan kualitas hidup pada lansia

\begin{tabular}{lccccccc}
\hline & $\begin{array}{c}\text { Kualitas } \\
\text { hidup } \\
\text { baik }\end{array}$ & $\begin{array}{c}\text { Kualitas } \\
\text { hidup } \\
\text { buruk }\end{array}$ & Total & & p \\
\cline { 2 - 6 } & $\mathbf{f}$ & $\%$ & $\mathbf{f}$ & $\%$ & $\mathbf{f}$ & $\%$ & \\
\hline $\begin{array}{l}\text { Kemungkinan } \\
\text { tidak depresi }\end{array}$ & 48 & 96 & 2 & 4 & 50 & 100 & \\
Kemungkinan & 38 & 76 & 12 & 24 & 50 & 100 & \\
depresi & & & & & & & \\
\hline
\end{tabular}

Pada Tabel 4 terlihat 50 sampel kemungkinan tidak depresi didapatkan 96\% memiliki kualitas hidup baik dan $4 \%$ memiliki kualitas hidup buruk, sedangkan pada sampel kemungkinan depresi didapatkan $76 \%$ memiliki kualitas hidup baik dan 24\% memiliki kualitas hidup buruk.

Hasil uji analisis Chi-square memperlihatkan nilai $p=0,004(p<0,05)$ antara kemungkinan depresi dengan kualitas hidup pada lansia di Kelurahan Surau Gadang wilayah kerja Puskesmas Nanggalo Padang.

\section{PEMBAHASAN}

Sebagian besar responden berada pada rentang usia 60-74 tahun yaitu sebanyak $82 \%$. Hal ini dikarenakan angka usia harapan hidup di Indonesia pada tahun 2015 berada pada angka 70,8 tahun dan diproyeksikan pada tahun 2030-2035 usia harapan hidup berada pada usia 72,2 tahun. $^{2}$ Status perkawinan yang terbanyak pada responden adalah berstatus menikah (59\%). Hal ini sesuai dengan data yang dikemukakan oleh Kementrian Kesehatan RI tahun 2017 yaitu lanjut usia yang masih memiliki pasangan hidup lebih banyak dibandingkan dengan yang tidak yaitu sebesar $59,78 \% .^{3}$ Sebagian besar responden juga berjenis kelamin perempuan, hal ini karena angka harapan hidup pada perempuan lebih tinggi dibandingkan dengan yang laki-laki. ${ }^{2,3}$

Pendidikan terakhir pada responden terbanyak adalah pada tingkat SMA/Sederajat (34\%). Hal ini dikarenakan sebagian besar penduduk di wilayah Nanggalo bekerja sebagai Pegawai Negeri Sipil yang memiliki tingkat pendidikan yang cukup tinggi. ${ }^{15}$ Pekerjaan pada responden mayoritas berstatus tidak bekerja (73\%). Hal ini sesuai dengan data yang dikemukakan oleh Kementrian Kesehatan RI tahun 2016 bahwa lanjut usia yang bekerja lebih sedikit (34\%) dibanding dengan yang tidak bekerja. Seiring dengan bertambahnya umur, maka fungsi fisiologis juga mengalami penurunan dan daya tahan tubuh juga mulai menurun sehingga menyebabkan lanjut usia rentan terhadap penyakit, sehingga tidak mampu untuk bekerja. $^{2}$

Penelitian ini juga menunjukkan bahwa rentang usia 74-90 tahun adalah rentang usia terbanyak pada lansia kelompok kemungkinan depresi (55,6\%). Hal ini sejalan dengan penelitian yang dilakukan di Campina 
Grande, Brazil pada tahun 2015 yang menyimpulkan bahwa dengan pertambahan usia dapat menjadi risiko untuk terjadinya depresi. ${ }^{16}$ Penelitian ini juga sejalan dengan penelitian yang dilakukan di Puskesmas Kubu II Bali pada tahun 2014 yang mendapatkan bahwa pada kelompok depresi yang terbanyak adalah rentang usia 74-90. ${ }^{10}$ Kelompok kemungkinan depresi berjenis kelamin perempuan lebih banyak yaitu sebesar $50,7 \%$ dibandingkan dengan yang berjenis kelamin laki-laki. Hasil ini sesuai dengan penelitian yang dilakukan di Universitas Udayana, Bali pada tahun 2015 yang mana jumlah lansia perempuan yang mengalami depresi lebih mendominasi dibandingkan dengan laki-laki. ${ }^{4}$ Hal ini dikarenakan dampak dari perubahan biologis terutama hormonal dan secara psikososial perempuan lebih memiliki banyak peran yang harus disandang, yang dapat menjadi stressor dan memicu terjadinya depresi. $^{17}$

Tingkat pendidikan yang ada pada kelompok kemungkinan depresi $68,2 \%$ responden memiliki pendidikan terakhir pada tingkat SMP/Sederajat. Penelitian ini sesuai dengan penelitian yang dilakukan di Afrika Selatan pada tahun 2013 yang menyatakan bahwa lansia yang lebih rentan terkena depresi adalah yang memiliki pendidikan rendah. ${ }^{18} \mathrm{Hal}$ ini juga sesuai dengan penelitian yang dilakukan di Universitas Udayana, Bali pada tahun 2015 yang menyatakan bahwa responden yang mengalami depresi lebih banyak yang memiliki pendidikan yang rendah. Pendidikan yang rendah menyebabkan semakin sulit seseorang untuk mengatasi masalah dan menerima informasi, sehingga hal ini dapat menjadi faktor risiko terjadinya depresi. ${ }^{4}$

Status perkawinan yang ada pada kelompok kemungkinan depresi yang terbanyak adalah berstatus duda. Penelitian yang dilakukan pada tahun 2015 di Brazil, menyatakan bahwa lansia yang tidak memiliki pasangan lebih rentan untuk mengalami depresi. ${ }^{16}$ Lansia yang masih hidup bersama pasangannya dapat saling berbagi dan mendukung dalam menghadapi masa tua, sehingga risiko depresi menjadi lebih rendah. ${ }^{4}$ Penelitian ini sejalan dengan penelitian yang dilakukan di Universitas Padova, Italia pada tahun 2016 yang menyatakan bahwa duda lebih rentan mengalami depresi dibandingkan janda, dikarenakan wanita memiliki mekanisme koping yang lebih baik dan lebih bisa mengekspresikan emosinya. ${ }^{19}$ Dari segi pekerjaan, pada kelompok kemungkinan depresi 53,4 $\%$ lanjut usia tidak memiliki pekerjaan. Hal ini sejalan dengan penelitian yang dilakukan di Manado pada tahun 2012 yang mana 25,5\% lansia yang mengalami depresi lebih banyak yang tidak bekerja atau sebagai ibu rumah tangga. ${ }^{17}$ Lansia yang tidak bekerja akan memiliki banyak waktu kosong karena sedikitnya aktivitas. Minimnya aktivitas tersebut akan mendorong munculnya rasa jenuh pada lansia dan dapat memicu terjadinya depresi. $^{20}$

Pada penelitian ini, dari 100 responden yang telah diwawancarai didapatkan $86 \%$ yang dikategorikan memiliki kualitas hidup yang baik dan $14 \%$ dikategorikan memiliki kualitas hidup buruk. Kualitas hidup mayoritas responden pada masing-masing domain adalah baik, sehingga responden yang memiliki kualitas hidup yang baik lebih dominan dibandingkan dengan yang buruk.

Hasil penelitian ini sesuai dengan penelitian yang dilakukan di kota Belo Horizonte, Minas Gerais, Brazil pada tahun 2016 yang menunjukkan bahwa mayoritas lanjut usia memiliki kualitas hidup yang baik $(63,4 \%) .{ }^{21}$ Penelitian lain yang dilakukan oleh Setiati et al pada tahun 2010 di 43 kota di Indonesia juga menunjukkan hal yang sama yaitu mayoritas lansia $(85,1 \%)$ yang tinggal di komunitas memiliki kualitas hidup baik. ${ }^{22}$ Lingkungan adalah salah satu faktor yang menyebabkan kualitas hidup lansia di Indonesia lebih tinggi dibandingkan di Brazil. Menurut Global Age Watch 2015, berdasarkan domain lingkungan Indonesia berada pada peringkat ke-8 dari 96 negara di dunia dengan nilai $79 \%{ }^{23}$

Penelitian ini menemukan terdapat hubungan bermakna antara kemungkinan depresi dengan kualitas hidup. Hasil ini sesuai dengan penelitian yang dilakukan di SDM College of Medical Sciences di Ujire, India pada tahun 2013 yang menyimpulkan bahwa terdapat korelasi antara depresi dengan kualitas hidup pada lansia yang berada di panti jompo. ${ }^{12}$ Penelitian lain yang dilakukan di Kali Anyar, Jakarta Barat pada tahun 2014 juga menyatakan bahwa depresi (gangguan mental) mempunyai hubungan dengan kualitas hidup secara keseluruhan dengan keempat 
domain kualitas hidup. ${ }^{13}$ Depresi dapat menimbulkan perubahan secara fisik, pemikiran, perasaan dan perilaku, yang mana hal ini dapat menetap dan menganggu aktifitas keseharian seseorang, sehingga dapat menganggu kualitas hidup pada seseorang, terutama pada lanjut usia. ${ }^{24}$

\section{SIMPULAN}

Terdapat hubungan yang bermakna antara kemungkinan depresi dengan kualitas hidup lanjut usia di Kelurahan Surau Gadang wilayah kerja Puskesmas Nanggalo Padang.

\section{DAFTAR PUSTAKA}

1. Peraturan Pemerintah Republik Indonesia nomor 43 Tahun 2004 tentang pelaksanaan upaya peningkatan kesejahteraan sosial lanjut usia. 2004.

2. Kementrian Kesehatan Republik Indonesia. Situasi lanjut usia (lansia) di Indonesia. Pusat Data dan Informasi Kementrian Kesehatan RI; 2016.

3. Kementrian Kesehatan Republik Indonesia. Analisis lansia di Indonesia. Jakarta: Pusat Data dan Informasi Kementrian Kesehatan RI; 2017.

4. Prabhaswari L, Ariastuti NLP. Gambaran kejadian depresi pada lanjut usia di wilayah kerja Puskesmas Petang I Kabupaten Badung Bali 2015. Jurnal Medika Udayana. Bali: 2015 Sept-Des;7(1):1-6.

5. Badan Pusat Statistik. Statistik penduduk lanjut usia 2016. Jakarta :Badan Pusat Statistik; 2017.

6. Sutikno E. Hubungan fungsi dengan kualitas hidup lansia (tesis). Surakarta: Universitas Sebelas Maret; 2011.

7. Setiati S, Harimurti K, Roosheroe AG. Proses menua dan implikasi kliniknya. Dalam: Sudoyo AW, Setiyohadi B, Alwi I, Simadibrata M, Setiati $\mathrm{S}$, editor (penyunting). Buku ajar ilmu penyakit dalam jilid III. Edisi ke-4. Jakarta: Pusat Penerbitan IImu Penyakit Dalam FKUI; 2006. hlm.1345-50.
8. Das J, Farzana FD, Ferdous F, Ahmed S, Tegenfeldt S, Paul RC, et al. Factors associated with elderly depression among rural Bangladesh individuals. American Journal of Psychiatry and Neuroscience. 2014 Jan 20; 2(1): 1-7.

9. World Health Organization (WHO). Depression. depression and other common mental disorders. Geneva: WHO; 2017.

10. WWSPR Bhayu IGM Agus, Ratep N, Westa W. Gambaran faktor-faktor yang mempengaruhi tingkat depresi pada lanjut usia di wilayah kerja Puskesmas Kubu II Januari-Februari 2014. Jurnal Medika Udayana. 2015; 4(1):1-14.

11. Kindig DA, Booske BC, Remington PL Mobilizing action toward community health (MATCH): Metrics, incentives, and partnerships for population health. The Journal of the American Medical Association. 2010 July;7(4):1-2.

12. Rasquinha DM, Acharya YTB. Relationship between depression and quality of life among institutionalised elderly. International jounal of scientific research. 2013 Oct;2(10):1-3.

13. Haris ER, Steven R, Handajani YS. Kualitas hidup pada lansia dengan gangguan kognitif dan mental: studi cross sectional di Kelurahan Kalianyar Jakarta Barat. Journal of Medicine. 2014 Jun;13(2): 117-27.

14. Hayati M. Gambaran tingkat depresi pada lansia di RW XIV Kelurahan Surau Gadang wilayah kerja Puskesmas Nanggalo Kecamatan Nanggalo Padang (skripsi). Padang: Politeknik Kesehatan Kemenkes Padang; 2015.

15. Saputra M. Depresi pada wanita menopause dan hubungannya dengan kualitas hidup (tesis). Padang: Universitas Andalas; 2011.

16. Lopes JM, Fernandes SGG, Dantas FG, Medeiros JVA. Association between depression and sociodemographic characteristics, quality of sleep and living habits among the elderly of the north-east of Brazil: a cross-sectional population based study, Rev Bras Geriatr Gerontol. 2015; 18(3):521-31. 
17. Ballo IR, Kaunang TMD, Munayang $\mathrm{H}$, Elim $\mathrm{C}$. Profil lanjut usia dengan depresi yang tinggal di Balai Penyantunan Lanjut Usia Senja Cerah Manado. Jurnal Biomedik. 2012 Maret; 4(1): 59-67.

18. Peltzer K, Mafuya PN. Depression associated factors in older adults in South Africa. Glob Health Action. Januari 2013;6:1-9.

19. Trevisan C, Veronese N, Maggi S, Baggio G, Rui MD, Bolzetta F, et al. Marital status and frailty in older people gender differences in the progetto veneto anziani longitudinal study. Journal of woman's health. 2016;25(6):630-7.

20. Centers for Disease Control and Prevention (2016). HRQOL Concepts (diunduh Februari 2018). Tersedia dari: https://www.cdc.gov/ $\underline{\mathrm{hrqol} / \text { concept.htm }}$
21. Miranda LCV, Soares SM, Silva PAB. Quality pf life and associated factors in elderly people at a reference center. Ciencia \& Saude Coletiva. Februari 2016;21(11):3533-44.

22. Setiati S, Harimurti K, Dewiasty E,Istanti R.Predictors and system for health-related quality of life in an Indonesian community-dwelling elderly population. Acta med-indones J Intern Med. 2011: 237-42.

23. Global Age Watch Index. Global Age watch index 2015: Insight report. London: HelpAge International; 2015.

24. Departemen Kesehatan RI. Pharmaceutical care untuk penderita gangguan depresif. Jakarta: Departemen Kesehatan Rl; 2007. 